\title{
Development, validation, and evaluation of an assay for the detection of wood frogs (Rana sylvatica) in environmental DNA
}

\author{
Mark A. Spangler ${ }^{1,2} \cdot$ Falk Huettmann $^{1} \cdot$ Ian C. Herriott ${ }^{3} \cdot$ J. Andrés López $^{2,4}$
}

Received: 6 November 2016 / Accepted: 6 October 2017 / Published online: 17 October 2017

(C) The Author(s) 2017. This article is an open access publication

\begin{abstract}
We developed and describe a qPCR assay for the detection of wood frogs (Rana sylvatica) using environmental DNA (eDNA) sampling. A single primer set was designed to amplify a 115-bp region of the wood frog cytochrome B gene and assessed for target specificity. There was no evidence of amplification in 11 non-target species. We evaluated the utility of the primer set in qPCR assay by conducting geo-referenced eDNA field surveys in Interior Alaska. Results indicate that the assay consistently detects wood frog DNA in the environment to $1.83 \times 10^{-3} \mathrm{pg} / \mu \mathrm{L}$. The assay provides a complement to traditional survey methods and can be readily applied in a wider conservation and management context.
\end{abstract}

Keywords eDNA · Wood frog $\cdot$ Rana sylvatica . Cytochrome B · Alaska

Electronic supplementary material The online version of this article (doi:10.1007/s12686-017-0881-3) contains supplementary material, which is available to authorized users.

Mark A. Spangler

maspangler@alaska.edu

1 EWHALE Lab - Institute of Arctic Biology, Biology and Wildlife Department, University of Alaska Fairbanks (UAF), 902 N. Koyukuk Dr., Fairbanks, AK 99775, USA

2 University of Alaska Museum of the North (UAM), 907 Yukon Drive, Fairbanks, AK 99775, USA

3 DNA Core Facility, Institute of Arctic Biology, University of Alaska Fairbanks (UAF), 909 N. Koyukuk Dr., Fairbanks, AK 99775, USA

4 Fisheries Division, College of Fisheries and Ocean Sciences, University of Alaska Fairbanks (UAF), 905 N. Koyukuk Dr., Fairbanks, AK 99775, USA
Wood frogs (Rana sylvatica, ITIS TSN: $775117^{1}$ ) are widely distributed across North America. Northern wood frogs are a sentinel species for amphibian response to climate change and land development (Benard 2015; Davenport et al. 2016; Winter et al. 2016). A species of greatest conservation need in Alaska, increased monitoring and research efforts are needed (Fields and Gotthardt 2009). Wood frog distribution in Alaska is not well-defined (Online Resource 1), nor are state population trends well-known (Anderson 2004; Gotthardt et al. 2014). Wood frog monitoring efforts in the north are complicated due to challenges associated with surveying large expanses of uninhabited wilderness. Further, an abbreviated aquatic breeding period limits acoustic survey opportunities.

Environmental DNA (eDNA) monitoring refers to the detection of trace macro-organismal DNA in the environment, most often water, soil, or feces (Bohmann et al. 2014). It is increasingly being used in quantitative surveys of aquatic ecosystems (Thomsen and Willerslev 2015). eDNA assays often provide improved detectability over traditional survey methods, but they also pose unique challenges including non-standardized protocols, PCR inhibition, and environmental influences on DNA degradation rates (Olson et al. 2012; Bohmann et al. 2014; Biggs et al. 2015). Further, the use of eDNA techniques for the detection of semi-aquatic species in ephemeral wetlands (e.g. wood frogs) has not been extensively assessed (McKee et al. 2015a). Conditions in ephemeral wetlands may be unfavorable for preservation and detection of DNA due to elevated temperatures, high sediment load, and high acidity contrasted with lakes and streams (Dejean et al. 2011; Barnes et al. 2014; Eichmiller et al. 2014). Here, we report the design and validation of a qPCR assay for detection of wood frogs in eDNA at the northern extent of the species' range.

${ }^{1}$ ITIS considers Rana sylvatica invalid, but see Yuan et al. 2016. 
We designed a species-specific primer set to target the cytochrome B gene of the wood frog mitochondrial genome. Sequences from the western clade of wood frogs were obtained from GenBank (PopSet 166030264, Lee-Yaw et al. 2008). The Rasy_00 primer set (Rasy_00_F: TCCTTCATC AAACAGGATCATCTA, Rasy_00_R: CCTAGTATAATG GTGAAGCCGAAT) was developed using Primer3Plus and tested for specificity in silico using NCBI Primer-BLAST (Online Resources 2 and 3). We tested Rasy_00 in vitro to ensure positive amplification of six high-quality wood frog genomic DNA isolates, as well as $500 \mathrm{~mL}$ of eDNA filtrate obtained from the aquarium of a live individual (Alaska Department of Fish and Game fish resource permit \#SF2016-029; Online Resource 4). No other amphibians co-occur at the northern range of the wood frog, though to assess specificity in vitro we tested Rasy_00 against genomic isolates from closely related and/or co-occurring aquatic species using the qPCR assay described below. Rasy_00 consistently amplified wood frog DNA with $100 \%$ specificity (Table 1).

We collected $1 \mathrm{~L}$ water samples from 60 wetlands near Fairbanks, AK throughout the breeding season to assess field performance of the eDNA assay (Online Resource 5). Opportunistic visual and acoustic observations were recorded at each site. Water samples $(n=155)$ were kept cool and dark and filtered within $24 \mathrm{~h}$ of collection. We vacuum filtered water samples through $0.45 \mu \mathrm{m}$ cellulose-nitrate membranes until they became clogged $(0.1-1 \mathrm{~L})$. Each batch of sample filtrations included a filter blank of distilled water $(n=18)$. Filter membranes were preserved at $-80^{\circ} \mathrm{C}$ for less than 6 months until DNA isolation.

We isolated total genomic eDNA from filter membranes using a modified phenol-chloroform protocol (Renshaw et al. 2015; http://dx.doi.org/10.17504/protocols.io.hnfb5bn). Each batch of DNA isolations included a negative control

Table 1 Primer Rasy_00 species specificity, as tested in vitro using genomic DNA extracts

\begin{tabular}{ll}
\hline Species + ITIS TSN & Amplification \\
\hline Wood frog (Rana sylvatica, 775117) & + \\
Columbia spotted frog (Rana luteiventris, 550546) & - \\
American bullfrog (Rana catesbeiana, 775084) & - \\
Northern leopard frog (Rana pipiens, 775108) & - \\
Rough-skinned newt (Taricha granulosa, 173620) & - \\
Arctic Grayling (Thymallus arcticus, 162016) & - \\
Least cisco (Coregonus sardinella, 161938) & - \\
Sockeye salmon (Oncorhynchus nerka, 161979) & - \\
Northern pike (Esox lucius, 162139$)$ & - \\
Alaska blackfish (Dallia pectoralis, 162159) & - \\
Arctic lamprey (Lethenteron camtschaticum, 622287) & - \\
Slimy sculpin (Cottus cognatus, 167232) & -
\end{tabular}

Table 2 qPCR results of wood frog eDNA field surveys

\begin{tabular}{lccccr}
\hline & \multicolumn{5}{l}{ Successful qPCR replicates (n of 4) } \\
\cline { 2 - 6 } & 0 & 1 & 2 & 3 & 4 \\
\hline Sites $(\mathrm{n}=60)$ & 25 & 19 & 9 & 3 & 4 \\
Negatives $(\mathrm{n}=28)$ & & & & & \\
$\quad$ Filter blanks & 15 & 3 & 0 & 0 & 0 \\
Isolate blanks & 8 & 2 & 0 & 0 & 0 \\
\hline
\end{tabular}

Raw data available via Dryad, http://dx.doi.org/10.5061/dryad.b7g24

with no filter membrane $(\mathrm{n}=10)$. All pre-PCR work was conducted in a PCR-free building. DNA isolates were used as templates in a qPCR assay with the Rasy_00 primers. All qPCRs were conducted in replicate $(4 \times)$ on an Applied Biosystems 7900HT Sequence Detection System. PCR conditions were as follows for $20 \mu \mathrm{L}$ reactions: $10 \mu \mathrm{L} 2 \times$ KAPA SYBR Universal MasterMix, $0.4 \mu \mathrm{L} 10 \mu \mathrm{M}$ each primer, $0.4 \mu \mathrm{L} 50 \times$ ROX dye, $1.25 \mu \mathrm{L} 100 \%$ DMSO, and $5 \mu \mathrm{L}$ template DNA (diluted 1:200, as determined by serial dilution). Thermal cycling conditions were $1 \times\left(94{ }^{\circ} \mathrm{C} / 4 \mathrm{~min}\right)$, $40 \times\left(94{ }^{\circ} \mathrm{C} / 30 \mathrm{~s}, 55^{\circ} \mathrm{C} / 45 \mathrm{~s}, 72{ }^{\circ} \mathrm{C} / 45 \mathrm{~s}\right)$ and a melt-curve analysis of $1 \times\left[94{ }^{\circ} \mathrm{C} / 15 \mathrm{~s}, 55^{\circ} \mathrm{C} / 15 \mathrm{~s}, 94^{\circ} \mathrm{C} / 15 \mathrm{~s}(2 \%\right.$ ramp rate)]. Results were scored as the number of positive replicates. Stochastic variation among replicates was observed due to low eDNA concentrations. A relaxed interpretation (qPCR score $=1$ ) risks false positive detection resulting from sample contamination, necessitating a cutoff score $\geq 2$ to confidently infer species presence (Table 2). All sites with visual/acoustic detection $(n=13)$ had scores $\geq 2$. Non-target amplifications resulting from primer-dimer artefacts were produced in the absence of template molecules in both negative control and unknown samples. They were excluded from the results through melt-curve analysis (Gudnason et al. 2007). A subset $(n=8)$ of positive samples were confirmed as wood frog DNA via Sanger sequencing (GenBank accession \#MG002391-MG002398). The limit of detection for the qPCR assay was assessed on a Qubit 2.0 Fluorometer using a dilution series of DNA extracted from wood frog liver tissue (UAM:Herp:122) at $1.83 \times 10^{-3} \mathrm{pg} / \mu \mathrm{L}$.

Our findings suggest eDNA detection is a viable survey method for semi-aquatic species in ephemeral wetlands. The assay described here may be improved by substituting DNA template dilution with a pre-PCR column-based purification step to reduce assay variance (McKee et al. 2015b). The widespread use of this assay can provide baseline northern wood frog occurrence data for use in spatial analyses (Spangler et al. unpublished).

Acknowledgements Partial funding was kindly provided by the Alaska Herpetological Society, the University of Alaska Fairbanks Department of Biology and Wildlife (Calvin J. Lensink Graduate Fellowship in Wildlife Biology), and the University of Alaska Fairbanks 
Institute of Arctic Biology (IAB Summer Graduate Research Fellowship). We thank J. Ream and A. Wenninger for providing assistance in collecting eDNA samples from captive amphibians, G. Zedda for laboratory assistance, and A. Matter for guidance with eDNA techniques. The University of Alaska Museum of the North provided tissue and DNA samples. B. Barnes and K. Kielland assisted with field site selection and access.

Open Access This article is distributed under the terms of the Creative Commons Attribution 4.0 International License (http://creativecommons.org/licenses/by/4.0/), which permits unrestricted use, distribution, and reproduction in any medium, provided you give appropriate credit to the original author(s) and the source, provide a link to the Creative Commons license, and indicate if changes were made.

\section{References}

Anderson BC (2004) An opportunistic amphibian inventory in Alaska's national parks 2001-2003. Anchorage. National Park Service, Inventory and Monitoring Program, Alaska

Barnes MA, Turner CR, Jerde CL, Renshaw MA, Chadderton WL, Lodge DM (2014) Environmental conditions influence eDNA persistence in aquatic systems. Environ Sci Technol 48(3):1819-1827

Benard MF (2015) Warmer winters reduce frog fecundity and shift breeding phenology, which consequently alters larval development and metamorphic timing. Glob Chang Biol 21.3:1058-1065

Biggs J, Ewald N, Valentini A et al (2015) Using eDNA to develop a national citizen science-based monitoring programme for the great crested newt (Triturus cristatus). Biol Conserv 183:19-28

Bohmann K, Evans A, Gilbert MTP, Carvalho GR, Creer S, Knapp M, Yu DW, De Bruyn M (2014) Environmental DNA for wildlife biology and biodiversity monitoring. Trends Ecol Evol 29(6):358-367

Davenport JM, Hossack BR, Fishback L (2016) Additive impacts of experimental climate change increase risk to an ectotherm at the Arctic's edge. Glob Chang Biol. doi:10.1111/gcb.13543

Dejean T, Valentini A, Duparc A, Pellier-Cuit S, Pompanon F, Taberlet P, Miaud C (2011) Persistence of environmental DNA in freshwater ecosystems. PLoS ONE 6(8):e23398. doi:10.1371/journal. pone.0023398

Eichmiller JJ, Bajer PG, Sorensen PW (2014) The relationship between the distribution of common carp and their environmental DNA in a small lake. PLoS ONE 9(11):e112611. doi:10.1371/journal. pone.0112611
Fields T, Gotthardt T (2009) The Alaska species ranking system: setting priorities for wildlife conservation. Final report. Prepared for the Alaska Department of Fish and Game, Nongame Program. Alaska Natural Heritage Program, Environment and Natural Resources Institute, University of Alaska Anchorage, Anchorage, AK. http://aknhp.uaa.alaska.edu/species_summary_reports/ pdfs/338.pdf. Accessed 7 July 2016

Gotthardt T, Pyare S, Huettmann F, Walton K, Spathelf M, Nesvacil K, Baltensperger A, Humphries G, Fields T (2014) Predicting the range and distribution of terrestrial vertebrate species in Alaska. The Alaska Gap Analysis Project, University of Alaska, Alaska, pp $1-40$

Gudnason H, Dufva M, Bang DD, Wolff A (2007) Comparison of multiple DNA dyes for real-time PCR: effects of dye concentration and sequence composition on DNA amplification and melting temperature. Nucleic Acids Res 35(19):e127

Lee-Yaw JA, Irwin JT, Green DM (2008) Postglacial range expansion from northern refugia by the wood frog, Rana sylvatica. Mol Ecol 17(3):867-884

McKee AM, Calhoun DL, Barichivich WJ, Spear SF, Goldberg CS, Glenn TC (2015a) Assessment of environmental DNA for detecting presence of imperiled aquatic amphibian species in isolated wetlands. J Fish Wildl Manag 6(2):498-510

McKee AM, Spear SF, Pierson TW (2015b) The effect of dilution and the use of a post-extraction nucleic acid purification column on the accuracy, precision, and inhibition of environmental DNA samples. Biol Conserv 183:70-76

Olson ZH, Briggler JT, Williams RN (2012) An eDNA approach to detect eastern hellbenders (Cryptobranchus alleganiensis) using samples of water. Wild Res 39(7):629-636

Renshaw MA, Olds BP, Jerde CL, McVeigh MM, Lodge DM (2015) The room temperature preservation of filtered environmental DNA samples and assimilation into a phenol-chloroform-isoamyl alcohol DNA extraction. Mol Ecol Res 15(1):168-176

Thomsen PF, Willerslev E (2015) Environmental DNA: an emerging tool in conservation for monitoring past and present biodiversity. Biol Conserv 183:4-18

Winter M, Fiedler W, Hochachka WM, Koehncke A, Meiri S, De la Riva I (2016) Patterns and biases in climate change research on amphibians and reptiles: a systematic review. R Soc Open Sci 3(9): 160158

Yuan ZY, Zhou WW, Chen X et al (2016) Spatiotemporal diversification of the true frogs (Genus Rana): a historical framework for a widely studied group of model organisms. Syst Biol 65(5):824-842 